\title{
Teoria jako ontologiczna retoryka: Rousseau i krystalizacja dyskursu pedagogicznego ${ }^{*}$
}

\section{KEYWORDS}

rhetoric, ontology, education, the political, Rousseau

\begin{abstract}
Szkudlarek Tomasz, Teoria jako ontologiczna retoryka: Rousseau i krystalizacja dyskursu pedagogicznego [Theory as ontological rhetoric: Rousseau and the crystallization of the discourse of education]. Kultura - Społeczeństwo - Edukacja nr 2(12) 2017, Poznań 2017, pp. 55-82, Adam Mickiewicz University Press. ISSN 2300-0422. DOI 10.14746/kse.2017.12.3.

Assuming the ontological understanding of rhetoric, as proposed by Ernesto Laclau, the paper explores the language of educational theories in their dimensions significant in terms of the discursive construction of societies. The tropes and rhetorical strategies identified in J.J. Rousseau's works are assumed as the point of departure for the crystallization of the modern discourse of education, here understood as an ontologically indispensable element of the political.
\end{abstract}

Niniejszy tekst jest skrótową i cząstkową prezentacją wyników analiz dokonanych $\mathrm{w}$ realizowanym obecnie projekcie badawczym, zorientowanym na identyfikację retoryk teorii i polityk edukacyjnych w kontekście ich związku z politycznymi

\footnotetext{
* Tekst został przygotowany w ramach projektu „Teorie pedagogiczne, polityki oświatowe a polityczna konstrukcja społeczeństwa. Analiza relacji w świetle 'retoryki ontologicznej' E. Laclau" finansowanego z grantu NCN UMO-2014/15/B/HS6/03580. Jest realizowany przeze mnie we współpracy z Frankiem Anthonym Carusi z Massey University w Nowej Zelandii. Dotychczas ukazały się dwie publikacje z tego projektu - monografia: T. Szkudlarek, On The Politics of Educational Theory. Rhetoric, theoretical ambiguity, and the construction of society. London and New York 2017 oraz F.T. Carusi, Why bother teaching? Despairing the ethical through teaching that does not follow, „Studies in Philosophy and Education", 2017, doi:10.1007/s11217-017-9569-0.
} 
uwikłaniami pedagogiki. Retoryka jest tu pojmowana w wymiarze ontologicznym, jako powiązana z konstruowaniem form społecznych tożsamości (totalności - jak nazywa to Ernesto Laclau), a polityczne uwikłania pedagogiki nie są traktowane jako niedopuszczalna ideologizacja wychowania, lecz raczej jako niezbywalny element pedagogicznej racjonalności (i irracjonalności) i jeden z podstawowych powodów, dla których edukację zaliczyć można do centralnych problemów nowoczesnych społeczeństw.

Dlaczego mówię tu o retoryce? Zacznijmy od tego, że nowoczesna edukacja jest praktyką społeczną jednocześnie kształtującą i indywidualne podmiotowości, i społeczne totalności. Wikła to jej dyskurs w sprzeczności, które - w najlepszym razie z punktu widzenia logicznej spójności wywodu - ujmowane są jako sprzeczności dialektyczne, co zakłada, że realizacja celów edukacji winna wiązać się z ich zniesieniem: $\mathrm{z}$ wytworzeniem społecznej totalności, która byłaby jednocześnie realizacją ludzkiej wolności. Poczynając od Locke’a i Rousseau (którego Emil powinien być czytany tak, jak był pisany, czyli razem z Umowa społeczna), znajdujemy takie wizje w większości teorii pedagogicznych, a szczególnie w tych, które inspirowane są heglizmem. Takie gesty zniesienia sprzeczności można uznać za sprofanowane - w sensie Agambenowskim (Agamben, 2007) „zwrócone do użytku zwykłym ludziom" - eschatologie. Jak zauważa Daniel Tröhler (Tröhler, 2014), typowe dla pedagogiki nowoczesnej cele emancypacji podmiotu i budowy nowoczesnego porząaku społecznego to mutacje idei zbawienia duszy i budowy królestwa Bożego na ziemi. W tym sensie fundamenty europejskiego dyskursu pedagogicznego - łącznie z napięciem między podejściami „typu Rousseau” i „typu Herbarta” odzwierciedlają spór toczony w łonie teologii protestanckiej, a dokładniej - jak przekonuje Tröhler - między wizjami relacji jednostki i społeczeństwa u Kalwina i Lutra. Dodajmy jeszcze do tej kolekcji powiązań między pedagogiką i teologią, że, zdaniem Bernadette Baker (Baker, 2010), nowoczesny zwrot ku edukacji w Europie (i wynikająca $\mathrm{z}$ niego postępująca pedagogizacja problemów społecznych) nastąpił w momencie załamania się porządku społecznego fundowanego na religii, co miało miejsce po kilkudziesięcioletnich wojnach o reformę chrześcijaństwa. W edukacji dostrzeżono wtedy nadzieję na przywrócenie społecznej jedności, a rolę Kościoła - teraz już podzielonego i zantagonizowanego - miało przejąć państwo, którego konstrukcja wymagała pedagogicznej „produkcji” obywateli. To rozbudowane przypomnienie genetycznych związków pedagogiki i teologii ułatwi nam zrozumienie roli retoryki w pedagogice i pozwoli na zidentyfikowanie pierwszej, fundamentalnej dla dyskursu pedagogicznego retorycznej strategii - strategii konstruowania tożsamości (totalności). Retoryka nie jest tu jedynie ozdobnikiem języka; podobnie jak w języku religii, pełni funkcję organizującą jego strukturę, 
w tym zwłaszcza łącznika między logicznie niespójnymi twierdzeniami. Ta funkcja ulega komplikacji (ale nie eliminacji) w momencie powiązania pedagogiki z językiem naukowym, co widać znakomicie w teorii Herbarta - w tym tekście nie będzie jednak miejsca na jej analizę.

Dotychczas (por. Szkudlarek, 2017) wyodrębniłem trzy podstawowe toposy, które można uznać za główne wymiary dyskursu pedagogicznego:

- wspomniane już konstruowanie totalności (tożsamości, jedności) w wymiarze indywidualnym i społecznym;

- konstruowanie widzialności i niewidzialności;

- konstruowanie temporalności.

Są one wspierane przez liczne, w większości wobec nich pochodne, strategie i służące im figury retoryczne. Spośród nich byłem w stanie bardziej szczegółowo przeanalizować następujące strategie:

- konstruowania pustych znaczących;

- specyficznej figury czasu, którą można określić mianem „temporalnego wykroczenia";

- zwrotnej pracy metafor (chodzi tu o figurę copular metaphor opisaną przez F. Tony'ego Carusi - zob. Carusi, 2011; 2017);

- sakralizacji i profanacji;

- specyficznej dla pisarstwa pedagogicznego retoryki postulatywnej, tj. przesycenie tekstów pedagogicznych apelami powinnościowymi.

Wszystkie te figury i strategie są ze sobą ściśle powiązane. Ich podstawy znajdujemy u Rousseau, który otwarcie uznaje swoje pisarstwo za nasycone paradoksami, co oczywiście doprasza się retorycznego spoiwa jego wywodów. Rousseańska retoryka nie jest jednak jedynie jego osobistym sposobem radzenia sobie ze złożonością materii, jej elementy można odnaleźć - w różnych szczegółowych wariantach i intensywnościach - w językach Herbarta, polskiej pedagogiki socjalistycznej czy w koncepcji całożyciowego uczenia się (nawiążę do tej kwestii w końcowej części tekstu). Są to zatem - prawdopodobnie - ogólniejsze strategie wynikające z niemożności logicznego powiązania głównych wątków pedagogicznego myślenia. Tego rodzaju niemożność, i związana z nią fundamentalna rola retoryki w konstruowaniu dyskursu, została bardzo dobrze udokumentowana w analizach E. Laclau (por. zwłaszcza Laclau, 2009; 2014) dotyczących dyskursu politycznego.

Zamiast analitycznej, ale z konieczności bardzo skrótowej prezentacji wszystkich wymienionych tu strategii, postaram się przywołać ich elementy w bardziej syntetycznie potraktowanej rekonstrukcji zachodzących między nimi powiązań tak jak jawią się one w pracach Rousseau. Wydaje mi się, że, pomimo nieuchronnego zagęszczenia wątków, koncentracja na związkach między tymi strategiami 
pozwoli na jaśniejszą ich prezentację. W końcowej części tekstu zasygnalizuję obecność tych strategii w pozostałych analizowanych przeze mnie odmianach pedagogicznego myślenia.

\section{Samotność i wspólnota}

Tytuł tej części rozważań jest zapożyczony z książki Bronisława Baczki (Baczko, 1964), która trafnie określa podstawowy problem pisarstwa Rousseau: napięcie między założeniem przyrodzonego dobra i wolności jednostki (z natury samotnej, jak twierdził Rousseau ${ }^{1}$ ) z jednej, a potrzebą zbudowania racjonalnego porządku społecznego z drugiej strony. Zadanie intelektualne wynikające z tej trudnej relacji zostało lakonicznie ujęte w początkowym akapicie Umowy społecznej (dalej US): „Pragnę zbadać, czy może istnieć w ustroju społecznym jakaś reguła rządzenia prawowita i pewna, biorąc ludzi takimi, jakimi są, a prawa takimi, jak być mogą" (Rousseau, 2007). Ludzie „jacy są” są tu „dani”, określa ich natura, i są w istocie indywiduami; prawo jest zaś „zadane”, musi być ustanowione w odpowiedzi na indywidualną naturę podmiotu. Samo zaś pytanie: „czy może istnieć” wskazuje na świadomość problematyczności relacji między wolnością naturalnego człowieka a porządkiem społecznym regulowanym warunkami prawnego kontraktu. Co więcej, każda z tych konfliktowo usytuowanych idei sama jest wewnętrznie pęknięta, porządek cywilizacyjny niszczy bowiem własne fundamenty etyczne, tj. naturalną dobroć jednostek, którą natura ustanowiła na miłości samego siebie (amour de soi) oraz zdolności do empatii. W miejsce amour de soi pojawia się amour propre, miłość własna skupiona na „własnościach” dających jednostce przewagę nad innymi ${ }^{2}$. Konstrukcja współczesnego porządku społecznego musi w związku z tym odwoływać się do taktyk manipulowania ową wtórną miłością własnych własności - jak władza, prestiż czy majątek. W tej sytuacji strategia konstruowania społecznej totalności, opisywana zarówno w Emilu (dalej Em) jak i w Umowie społecznej czy w Uwagach o rzadzie polskim (dalej RP) musi zakładać dyskretną manipulację tkankami życia społecznego, bardzo zbliżoną do tej, jakiej w procesie „naturalnego" wychowania podlega Emil. Zarówno nauczyciel, jak i prawodawca - pierwszy

\footnotetext{
1 „Wszystko wychodząc z rąk Stwórcy jest dobre, wszystko wyrodnieje w rękach człowieka”. J.-J. Rousseau, Emil, czyli o wychowaniu, wyd. Polska Biblioteka Internetowa (epub), b.r.w., akapit 4.1. Format publikacji nie zawiera numerów stron, numerowane są poszczególne akapity.

${ }^{2}$ Trzeba w tym kontekście wspomnieć, że w wielu polskich opracowaniach to rozróżnienie jest trudne do dostrzeżenia; obie te formy miłości bywają tłumaczone są jako „miłość własna”, co zaciera ich przeciwstawienie.
} 
podmiot nowego porządku republikańskiego, tworzący jego zręby - przedstawiani są jako półboskie, a zarazem manipulatorskie figury. Pomimo fundamentalnej rangi, jaka przypisywana jest naturze, to, co w człowieku naturalne, musi bowiem zostać zniszczone, aby ustanowienie społeczeństwa było w ogóle możliwe:

Człowiek natury istnieje wyłącznie dla siebie; jest on jednością, całością bezwzględną, która uznaje jedynie siebie albo kogoś podobnego do siebie. Człowiek społeczny jest tylko jednostką ułamkową, zależną od mianownika, i której wartość polega na stosunku do całości, jaką jest społeczeństwo.

Dobre są te urządzenia społeczne, które najlepiej umieją wypaczyćc człowieka, odebrać mu jego istnienie absolutne, dając mu w zamian istnienie względne, i przenieść jego ja do jednostki zbiorowej tak, aby człowiek poszczególny nie czuł się więcej jednostką, ale częścią jednostki; i ażeby był wrażliwy tylko w łonie tej całości. (Rousseau, Emil..., akapit 4.18-4.19)

Napięcie między naturalnym dobrem i „bezwzględną całością” jednostki a potrzebą skonstruowania totalności społecznej („ciała politycznego”, spójnego społecznego organizmu, który znosi pierwotną integralność i autonomię podmiotu) musi się skondensować w sposobie definiowania podstawowego dla argumentacji Rousseau pojęcia natury. Jeśli natura stanowi nieodżałowany fundament dobra jednostkowego i społecznego, ale także transcendentnego (por. Wyznanie wiary wikarego sabaudzkiego z IV księgi Emila, wykładające podstawy religii naturalnej), i jeśli zarazem jest ona porzucana, a w zasadzie celowo eliminowana w procesie konstruowania totalności - to samo pojęcie natury musi zostać „zdenaturalizowane”. Jego wieloznaczność wzrasta szczególnie, gdy weźmiemy pod uwagę, że ugruntowanie w naturze przypisuje się nie tylko ludzkim jednostkom, ale i narodom (RP). Zapętlenia znaczeń przypisywanych temu pojęciu są zatem nieuchronne i prowadzą na przykład do takich tez, że dziecku trzeba „wpoić naturalną awersję do obcych" (RP; skoro awersja jest naturalna, to czemu trzeba ją wpajać?) albo

${ }^{3}$ Mam zastrzeżenia do tego przekładu. Mowa tu o paradoksalnej arytmetyce podmiotu społecznego, w której jego wartość - jako ułamka - jest tym większa, im większy jest jego mianownik, to znaczy że na przykład jedna milionowa jest silniejsza od jednej tysięcznej. W tym kontekście musi budzić wątpliwość użycie terminu „wypaczyć” w kolejnym akapicie. W oryginale Rousseau czytamy: „Les bonnes institutions sociales sont celles, qui savent le mieux dénaturer l'homme, lui ôter sonexistence absolue pour lui en donner une relative, et transporter le moi dans l'unité commune ..." Termin dénaturer może oczywiście być tłumaczony jako „wypaczenie” (lub „wynaturzenie”), ale użycie tego terminu w tym miejscu zdaje się świadczyć o uwiedzeniu tłumacza aurą naturalizmu i o przeoczeniu ambiwalentnej roli natury. Chodzi tu zaś po prostu o to, że instytucje społeczne muszą człowieka „zdenaturalizować", przekształcić go z bytu naturalnego w byt społeczny. Cytat z oryginału pochodzi z: J.-J. Rousseau (1762), Émile ou de léducation : livres I, II et III, s. 11, wydanie elektroniczne, Québec 2002, http://classiques.uqac.ca/classiques/Rousseau_jj/emile/emile_de_education_1_3.pdf. 
że narody Europy zanikają, bo „żaden z nich nie został ukształtowany przez instytucje stworzone zgodnie $\mathrm{z}$ ich naturą" (RP: skoro mają one swoje odrębne natury, to czemu trzeba je kształtować?). Bronisław Baczko (Baczko, 1964) uznaje próby rozwikłania sensu natury u Rousseau za skazane na klęskę, a Bernadette Baker stwierdza, że występuje ono jednocześnie w sześciu splatających się i swobodnie przemieszczanych znaczeniach:

Natura pojawia się [u Rousseau] jako stan pierwotny (np. w Pierwszym i Drugim dyskursie ) $^{4}$, jako niepohamowane zwierzęce pożądanie pozbawione religijnej i moralnej refleksji (np. w Drugim dyskursie), jako materia i siła (np. w Emilu), jako uniwersalne prawa ruchu (Emil), jako to, co nie zostało stworzone przez ludzi (np. Pierwszy dyskurs) i jako te potencjalności czy dyspozycje, które ujawniają się a posteriori pod wpływem instytucji stworzonych przez człowieka (np. Umowa społeczna). (Baker, 2010: 233)

To właśnie dzięki tej wieloznaczności, jak zauważa Baker, Rousseau może pisać o wychowaniu Emila jednocześnie dla społeczeństwa obywatelskiego i przeciw niemu; w logice polityki i w logice pedagogiki negatywnej zachowującej głos natury.

Taka multiplikacja sensów pojęcia natury prowadzi de facto do jego „semantycznego opróżnienia”: tworzy ona z pojęcia natury puste znaczące. Ten zabieg retoryczny, odpowiadający w retoryce klasycznej figurze katachrezy, w świetle teorii E. Laclau ${ }^{5}$ pozwala na spięcie dyskursu obejmującego sprzeczne ze sobą roszczenia klamrą nadającą mu walor totalności, co oznacza, że retoryka pełni tu funkcję ontologiczną. Jest to jedna z podstawowych kwestii dla rozumienia społecznego sensu pedagogiki jako publicznego dyskursu.

Podsumujmy ten fragment rozważań. Sprzeczność między afirmacją natury (szczególnie ludzkiej) a koniecznością ustanowienia porządku społecznego uruchamia kilka strategii konstruowania spójności wywodu, a w sferze wyrażanej w tekstach intencji - konstruowania spoistej tożsamości (totalności) świata. Po pierwsze, wiedzie to do multiplikacji sensu pojęcia natury w stopniu zacierającym pierwotnie mu przypisane znaczenie fundamentu wszystkich późniejszych kreacji (por. ostatnia wersja tej kategorii w typologii Baker) i skutkującym nadaniem mu statusu pustego znaczącego. Po drugie, rozmycie sensu tego pojęcia umożliwia po-

\footnotetext{
${ }^{4} \mathrm{~W}$ literaturze rousseauistycznej często używa się odniesień numerycznych do Dyskursów Rousseau: pierwszy to Discours sur les sciences et les arts (1750), konkursowy debiut rozpoczynający naukową karierę Rousseau, z tezą o upadku obyczajów spowodowanym rozwojem nauki i cywilizacji; drugi to Discours sur l'origine et les fondments de l'inegalite, (1754), będący sprzeciwem wobec społecznych nierówności, trzeci to Discours sur l'Économie politique - wykład ekonomii politycznej opublikowany w 1755 roku w Encyklopedii Diderota i d'Alemberta.

${ }^{5}$ E. Laclau, 2009; por. także moje wcześniejsze odniesienia do tej kategorii w analizach pedagogicznych, na przykład Szkudlarek, 2007; 2011; 2013; 2016. Najobszerniej podejmuję analizę pedagogicznego potencjału teorii Laclau w VI rozdziale The politics of educational theory.
} 
szukiwania natury również w konstrukcjach społecznych, co tylko pogłębia związane $\mathrm{z}$ tym pojęciem komplikacje $\mathrm{e}^{6}$. Po trzecie, naturze przypisano walor etyczny (wszystko, co wychodzi z rąk Stwórcy, jest dobre), przy czym w tym samym Emilu znajdujemy Wyznanie wiary wikarego sabaudzkiego, gdzie figura Stwórcy mówi do nas nie przez święte księgi i Kościoły, a przez naturę ${ }^{7}$. Jednocześnie ta sama natura wymaga „denaturalizacji” w celu wychowania człowieka społecznego. Proces tego przekształcania musi być postrzegany jako transformacja tego, co totalne, jako przejście od integralności i pojedynczości jednostki do integralności i pojedynczości społeczeństwa, określanego mianem „ciała politycznego”, „ciała moralnego i kolektywnego”, „publicznej osoby” (Em. ks. V; US). Jednocześnie - w kontekście wizji religii naturalnej wykładanej przez Wikarego - trzeba ten proces postrzegać jako profanację tego, co boskie. Dość łatwo zgadnąć, że taka transformacja dokonywana na ciałach i duszach integralnych jednostek nie może być ani łatwa do opisania z zachowaniem reguł logiki, ani łatwa do przeprowadzenia bez jakiejś formy zatarcia, zasłonięcia jej wewnętrznych sprzeczności.

Analiza retoryki przekształcania totalności (tożsamości, pojedynczości) wymaga zatem zidentyfikowania służących jej retoryk sakralizacji i profanacji. Przede wszystkim jednak okazuje się możliwa jedynie wtedy, gdy zidentyfikujemy w tekstach Rousseau dwie warstwy semantyczne, które nazywam za Laclau warstwą ontyczną i ontologiczną. Ich identyfikacja nie zawsze jest prosta ze względu na ciągłe ich splatanie, na nieustannie płynne przechodzenie pomiędzy tymi rejestrami. Generalnie, o ile to, co ontyczne, dotyczy treści bezpośrednich doświadczeń (na przykład doświadczeń edukacyjnych Emila lub zwyczajów życia publicznego Polaków), o tyle to, co ontologiczne, obejmuje proces konstruowania tych doświadczeń, a szerzej - samej konstruowalności społecznego i jednostkowego świata. To konstruowanie przybiera formę nie tyle bezpośredniej ingerencji w treść doświadczeń jednostkowych

\footnotetext{
${ }^{6}$ Ten element zapowiadam tu tylko marginalnie, dotyczy on głównie Uwag o rządzie polskim. Szerszą analizę przeprowadziłem w innym tekście: Szkudlarek, 2005: 19-38.

7 Jest to przykład metafory zwrotnej (copular metaphor) operującej wzajemnie wzmacniającymi się ruchami identyfikacji i gruntowania (Carusi, 2011; 2017). Skoro to, co istnieje niezależnie od człowieka (natura), jest stworzone przez Boga, to jest dobre; natura jest w ten sposób utożsamiona $\mathrm{z}$ dobrem (ruch identyfikacji). Dalej, skoro Bóg jest dobrem i natura jest tożsama z dobrem, to Bóg jest obecny w naturze (ruch ugruntowania). Zwrotność tego ruchu stabilizuje związek objętych nim elementów, tworząc z nich bardzo silną, quasi-pojęciową strukturę wiążącą elementy całego tekstu. Jej siła nie oznacza, że mamy tu do czynienia z logiczną precyzją - przeciwnie, jest to nadal metafora, czy też, mówiąc językiem Derridy, nierozstrzygalnik. Tego rodzaju serie metonimii i metafor można zidentyfikować jako leżące u podstaw teologii Rousseau, który, zachowując stanowisko deistyczne, zbliża się do panteizmu. Dalsze połączenia w tym łańcuchu, włączające do niego kategorie narodu i dziecka (obydwa pojęcia wiążą się z naturą przez rdzeń natus, narodzony), będą prowadzić do sakralizacji tych figur (por. dalej).
} 
i społecznych, ile kształtowania warunków możliwości ich zaistnienia i przekształcania. To zaś musi się odbywać w sposób dla jednostek i społeczeństw niezauważalny. Rousseau pisze zatem niejako dwa splecione ze sobą teksty w jednym i dotyczy to wszystkich przywoływanych tu publikacji. Pierwszy tekst obejmuje to, co ma być dla jednostek i dla społeczeństw widoczne, co jest treścią ich bezpośredniego doświadczania. Drugi adresowany jest do osób, które tym doświadczaniem mają sterować, które mają doprowadzić do przekształcenia człowieka natury w człowieka społecznego, do transformacji pozbawionej tożsamości zbiorowości w świadomy siebie naród bądź kolekcji indywiduów w kontraktowe społeczeństwo, w kierujące się wspólną wolą ciało polityczne. Ta druga warstwa tekstu opatrywana jest częstymi komentarzami dotyczącymi sposobów ukrywania charakteru działań odpowiedzialnych za takie przekształcenia. O ile zatem pierwotna, uznana za naturalną postać totalności (autonomiczny podmiot jednostkowy, ale także naród w jego „naturalnej”, antycznej postaci) ukazywana jest „w świetle” (jest dobra, autentyczna, sama sobie bezpośrednio dostępna, sama dla siebie widzialna), to ta druga - społeczna i narodowa - tworzy się w sferze niewidzialnego. Nieco komplikuje tę klarowną dychotomię to, że owo „ukazywanie się w świetle” tego, co naturalne, czasami wymaga pewnych zabiegów politycznych i pedagogicznych zachodzących w mroku - mianowicie pracy instytucji stworzonych „zgodnie z naturą" tego, co dopiero ma się ujawnić (por. ostatni wariant natury w typologii Baker ${ }^{8}$ ). Dotykamy tu tego, co ontologiczne: samego procesu konstruowania człowieka i społeczeństwa oraz warunków możliwości ich zaistnienia. Ów proces wymaga ingerencji nauczycieli i prawodawców, a jego warunkiem jest tej interwencji ukrycie.

A zatem, konstruowanie autonomicznego podmiotu (Em) i totalności społecznych (US, RP) rozgrywane jest przy użyciu toposów, strategii i figur rozpiętych na opozycjach: totalne - partykularne, sakralizacja - profanacja, oraz widzialność - niewidzialność. Przejdziemy teraz do analizy relacji sakralizacji i profanacji.

\section{Wymiary świętości, konstrukcja niewidzialnego i genealogia pedagogicznej winy}

Jak wspominałem, boska geneza dobra zawarta w otwierającym Emila zdaniu jest w tej samej książce utożsamiana z genezą naturalistyczną. Podstawianie natury pod figurę Boga to częsta praktyka osiemnastowiecznej kultury i Rousseau nie jest tu wy-

\footnotetext{
${ }^{8}$ Bardzo istotne jest tutaj pytanie o to, skąd znamy tę naturę, zanim się ona ujawni w efekcie pracy skonstruowanych w zgodzie z nią instytucji. Otwiera to problem tautologicznej założeniowości dyskursu pedagogicznego, o którym będę pisać dalej.
} 
jątkiem. Jak zauważa Fritz Osterwalder (Osterwalder, 2012: 432-447), pedagogika Rousseau jest inspirowana pedagogiką ruchu jansenistowskiego (nieortodoksyjna i w końcu zakazana przez Watykan doktryna cysterek z Port-Royal) i tradycją protestanckiego pietyzmu. Najważniejsze jest w tym kontekście proklamowanie przez Rousseau naturalistycznego pojmowania religii. To przyroda jest „księgą Autora rzeczy”, to w niej objawia się Jego wola. Jak można pogodzić takie stanowisko z manipulowaniem dziećmi, stanowiącymi najbardziej naturalną, a zatem najbardziej boską wersję człowieka, i manipulowanie semantycznie wywodzonymi z natury narodami ${ }^{9}$ ? Polityka i wychowanie muszą być w tym kontekście postrzegane jako gesty profanacji. Giorgio Agamben (Agamben, 2007) tłumaczy to pojęcie w ważny dla rozumienia tej kwestii sposób: profanacja to przywrócenie czegoś do użytku publicznego, oddanie zwykłym ludziom (profanom) tego, co zostało ze świata wyłączone, co wcześniej uległo sakralizacji i tabuizacji. Wychowanie i polityka byłyby w tym sensie nie tylko denaturalizacją, ale także desakralizacją człowieka i społeczeństwa ${ }^{10}$. Oba te gesty są fundamentalnie ważne dla procesu modernizowania świata, który zgodnie ze znaną Weberowską diagnozą, wymaga w tym celu odczarowania.

Sprawa jest jednak jeszcze bardziej złożona. Sakralny wymiar przysługuje bowiem zarówno figurze dziecka, jak i nauczyciela; narodu, jak i manipulującego jego naturą polityka. Właśnie w gestach dystrybucji świętości wspomniana wcześniej dystynkcja między ontycznym i ontologicznym wymiarem teorii ujawnia się w najczystszej postaci. Chyba najbardziej czytelnie wykłada to Rousseau, opisując figurę prawodawcy w Umowie społecznej:

Aby ustalić najlepsze, korzystne dla narodów reguły społeczne, potrzeba umysłu wyższego, który znałby wszystkie namiętności ludzkie, a sam nie doznawał żadnej; który byłby pozbawiony wszelkiego związku z naszą naturą, a znał ją gruntownie; którego szczęście byłoby od nas niezależne, a który jednak chciałby się naszym szczęściem zająć; który wreszcie, zachowując sobie w procesie dziejowym odległą sławę, mógłby pracować w jednym wieku, a zbierać plony w drugim. Trzeba by bogów, aby nadać ustawy ludziom. (Rousseau, 2007: 37)

Pojawienie się tu trybu warunkowego („trzeba by bogów” - a zatem ich nie mamy, nie możemy ich do tej pracy wynająć) zapowiada, że boskie zadanie usta-

9 Zarówno w łacinie, jak i w języku polskim „natio” (naród) , jak „natura” (przyroda) etymologicznie wywodzą się od rodzenia („natus”, narodzony).

${ }^{10}$ Kevin Inston zauważa w tym kontekście, że teza o nienaturalności społeczeństwa, opisywana przez Rousseau jako spowodowany rozwojem cywilizacji upadek tego, co wartościowe, jest jednocześnie otwarciem możliwości nowoczesnego pojmowania polityki. Świat społeczny nie jest przez Rousseau ujmowany jako zdeterminowany jego naturalnym bądź boskim pochodzeniem i może - a zarazem musi - być kształtowany przez ludzi, którzy muszą za niego wziąć odpowiedzialność (Inston, 2010). 
nawiania społeczeństwa musi być rozpisane na elementy czysto ludzkiej strategii. Oznacza to, że ludzki prawodawca sprofanuje pracę bogów, ale sam doświadczy przy tym deifikacji. Jego zadaniem jest przeprowadzić społeczeństwo do stanu, w którym wola jednostek stopi się w spójną wolę jednolitego „ciała politycznego”. Sama forma takiego społeczeństwa nie jest tu szczególnym problemem, wiadomo, jak ma ono wyglądać i Rousseau bardzo precyzyjnie opisuje procedury wyłaniania przedstawicieli, stanowienia ustaw, reguły głosowań itp. Boskim, ontologicznym problemem jest stworzenie warunków możliwości zaistnienia takiego społeczeństwa, zapewnienie możliwości wyłonienia się ciała politycznego. Jego powstanie Rousseau opisuje tak:

Każdy z nas wspólnie oddaje swoją osobę i całą swą potęgę pod naczelne kierownictwo woli powszechnej (...) i traktujemy każdego członka jak niepodzielną część całości.

Ten akt zrzeszenia tworzy natychmiast, w miejsce prywatnej osoby każdego kontrahenta, ciało moralne i zbiorowe, które złożone jest z tylu członków, ile zgromadzenie liczy głosów, które uzyskuje przez ten akt swoją jedność, swoje ja wspólne, swoje życie i swą wolę. (Rousseau, 2007: 20)

Dość łatwo sobie wyobrazić, że, przy założeniu pierwotnego indywidualizmu człowieka, tego rodzaju dobrowolne zrzeczenie się naturalnej, indywidualnej autonomii nie jest proste do pomyślenia bez wcześniejszego ustanowienia jakiejś formy wspólnotowego pragnienia. I właśnie w tym miejscu pojawia się konieczność quasi-boskiej interwencji. Pisząc o typach ustaw koniecznych dla funkcjonowania społeczeństwa republikańskiego, do trzech podstawowych, tj. politycznych, cywilnych i karnych, Rousseau dodaje typ czwarty - niepodlegający regulacji prawnej: ani przez obywateli niekontrolowany, ani nieuświadamiany:

Do tych trzech rodzajów ustaw dołącza się czwarty, najważniejszy ze wszystkich, wyryty nie w marmurze ani miedzi, ale w sercach obywateli. Stanowi on prawdziwą konstytucję państwa, nabiera z każdym dniem nowych sił, a gdy inne ustawy starzeją się lub wygasają, ożywia je na nowo albo uzupełnia, utrzymuje lud w duchu jego urządzeń i zastępuje dyskretnie władzę mocą przyzwyczajenia. Mówię tu o obyczajach, przyzwyczajeniach, a zwłaszcza o opinii, dziedzinie nieznanej naszym politykom, od której jednak zależy powodzenie we wszystkich innych; dziedzinie, którą wielki prawodawca zajmuje się w ciszy, gdy na pozór ogranicza się do przepisów szczegółowych, będących tylko członami sklepienia, którego zamykający niewzruszalny klucz wznoszą mozolnie powstające obyczaje. (Rousseau, 2007: 41)

Uzgodnione obyczaje, przyzwyczajenia i opinie stanowią zatem fundamentalny warunek możliwości funkcjonowania społeczeństwa republikańskiego. Nie są one jednak niczym naturalnym w sensie ich samorodnego powstawania. Są aktywnie formowane przez nadludzkiego prawodawcę, ale odbywa się to $w$ ciszy, 
w sposób dla ludzi podlegających temu formowaniu niezauważalny. Jest to bardzo dobry przykład konstruowania niewidzialności tego, co stanowi siłę realną ${ }^{11}$. To także bardzo mocny akcent dokonywanej tutaj rekonstrukcji, silnie spinający wizje Rousseau z koncepcjami radykalnej demokracji Laclau i Mouffe (por. przywoływana wcześniej rekonstrukcja związków ich teorii z filozofią Rousseau u Instona), co zarazem potwierdza tezę Laclau o ontologicznym wymiarze retoryki. Chodzi o to, że ontologiczne podstawy porządku politycznego nie sa tworzone $w$ racjonalnej debacie publicznej. Sama taka debata jest bowiem możliwa jedynie pod warunkiem podzielania pewnych przekonań (jak u Rousseau) oraz, jak dowodzi Laclau, pod warunkiem stworzenia retorycznych figur społecznej tożsamości. W żaden sposób nie są one możliwe do wypracowania na drodze racjonalnej, nie wynikają z żadnej uniwersalnej logiki historycznego rozumu w stylu Hegla czy Marksa. Paradoksalny, odwołujący się do emocji (fundament społecznego porządku lokowany „w sercach”) i przesycony retorycznymi figurami dyskurs Rousseau sam okazuje się potężnym narzędziem konstruowania społecznych rzeczywistości; jest $\mathrm{w}$ tym sensie stricte polityczny.

Manipulatorskie działanie boskiego prawodawcy odbywa się jednak na podmiotach również uznawanych za święte. Klasyczna rzymska maksyma vox populi vox dei jest przez Rousseau przywoływana bez zająknienia. Przedmiotem oddziaływań nauczyciela jest zaś naturalne, zatem dobre, zatem boskie dziecko. Deus sive natura, Spinozjańskie utożsamienie Boga i natury to niemal kanon osiemnastowiecznej kultury, wyraźnie odzwierciedlany w koncepcji religii naturalnej Rousseau. Do kompletu brakuje nam tylko dopowiedzenia, że działanie nauczyciela Emila projektowane jest przez Rousseau w pełni symetrycznie do działań prawodawcy. Traktat pedagogiczny przesycony jest zaleceniami dotyczącymi tworzenia niewidzialności. Zamiast bezpośredniej ingerencji w zachowanie i myślenie dziecka pojawiają się w nim liczne zabiegi demiurgicznego kreowania świata dziecka, tworzenia środowiska, w którym dziecko będzie zdobywać „naturalne”, kształtujące je doświadczenia. Poczynając od ukształtowania siebie jako wychowawcy, przez wywiezienie dziecka na wieś, po setki szczegółowych zaleceń dotyczących organizowania warunków możliwości doświadczenia edukacyjnego, wychowawca sytuuje się w roli kreatora naturalnie doświadczanego przez dziecko świata.

${ }^{11}$ Kwestia niewidzialności siły, czy też władzy, była często podejmowana w tradycji nietzscheańskiej. U Nietzschego wiąże się to z koncepcją podmiotu reaktywnego, dla którego tylko jego wewnętrzne pobudzenia (a nie to, co je realnie wywołuje) są dostępne bezpośredniemu postrzeganiu. Rozwinięcia tej obserwacji znajdujemy później u Foucaulta i Deleuzéa. Zauważmy, że jest to także bliskie behawiorystycznym nurtom psychologii. 
To właśnie tak można rozwiązać dylemat zasygnalizowany w otwierającym zdaniu Umowy społecznej - stworzyć porządek społeczny, zachowując wolność jednostek. Jak widzimy, wolność ta jest w procesie kreacji porządku limitowana do działań i wyborów dokonywanych w ustanowionym już horyzoncie doświadczenia, które gwarantować ma uspójnioną obyczajowość, moralność i opinię publiczną. Dla realizacji tego karkołomnego zadania wychowawca i prawodawca sam siebie dzieli na boskiego i niewidzialnego demiurga - i własna, widoczna dla dziecka i obywatela epifanię. Jak bóstwo mozolnie tworzy świat życia człowieka, zaczynając pracę na długo, zanim dziecko się w nim pojawi (pedagog musi na przykład zapracować sobie na uznanie i szacunek innych ludzi, aby dziecko od innych mogło słyszeć, że powinno nauczycielowi ufać - wrócę do tego wątku w trakcie omawiania pedagogicznej konstrukcji czasu) i nieustannie „podrzucając” do tego świata obiekty, które staną się treścią z wolna dawkowanych doświadczeń. Jako profan, człowiek jeden $z$ wielu, nauczyciel pojawia się w tym wykreowanym przez siebie świecie już jako niemal bierny, nieingerujący i życzliwy opiekun, towarzysz i obserwator, sporadycznie odpowiadający na pytania dziecka zainspirowane swoim własnym, wcześniejszym i bosko niewidocznym dla dziecka działaniem:

\begin{abstract}
Idźcie drogą przeciwną do tej, jaką podąża wasz uczeń; niech myśli, że on jest nauczycielem, a wówczas wy nim będziecie. Najzupełniejsze jest poddaństwo mające pozory swobody; $w$ ten sposób ujarzmia się właśnie wolę. Biedne dziecko, które nic nie umie, nic nie może, nic nie wie, czyż nie jest zdane na twoją łaskę? Czyż nie rozporządzasz w stosunku do niego wszystkim, co je otacza? Czy nie możesz używać władzy, jak ci się podoba? Praca jego, zabawa, przyjemności, smutki, czyż nie są - choć o tym nie wie - w twoich rękach? Niewątpliwie, powinno ono robić tylko to, co chce, ale powinno chcieć jedynie tego, czego ty chcesz; nie powinno uczynić kroku, którego nie przewidziałeś; nie powinno otworzyć ust, żebyś nie wiedział, co powie. (Rousseau, Em, par. 7.95)
\end{abstract}

Zainicjowana przez Rousseau strategia, znana później pod nazwą „kształtowanie środowiska wychowawczego", jest pod względem usytuowania w warstwie ontologicznej (stwarzania warunków możliwości ludzkich działań i doświadczeń) identyczna ze strategią projektowaną dla prawodawcy. Jest to strategia imitacji boskości (Osterwalder, 2012; Scott, 1994).

Co to jednak znaczy, że Bóg skrycie manipuluje czymś, co również jest boskie? Możemy mieć tu do czynienia albo ze zmieszaniem, albo z konfliktem, albo z hierarchią bogów. Jest to być może refleks dualnej figury Boga znanej z Genesis i z niektórych elementów tradycji gnostycznej. Ten wątek pojawia się u Gerta Biesty (za Johnem Caputo) w jego książce o ryzyku edukowania (Biesta, 2013). Caputo zauważa, że w Księdze Rodzaju mowa jest o Bogu podwójnej natury - albo 
o dwóch bogach (dodajmy, że być może o trzech, jeśli zaliczymy do bogów szatana, co by pięknie współgrało z triadycznymi grami Hegla ${ }^{12}$ ). Pierwszy określany jest imieniem Elohim (które - dodajmy - nie jest imieniem, bo pierwotnie było słowem w liczbie mnogiej określającym bogów lub generalnie boskość; w późniejszej tradycji uległo ono jednak „monoteizacji”) i pojawia się w opowieści o stworzeniu ziemi i nieba. Jak za Caputo pisze Biesta, to bóg - animator, inspirujący i ożywiający to, co jest. W przekładzie Genesis przywoływanym przez Caputo w stwarzanym świecie już istnieje ziemia (tyle że „pusta”), wody i wiatr. Boskie tchnienie ożywia je i nadaje im formę. Moment, w którym Bóg stwierdza, że efekt jego działań mu się spodobał, wskazuje zaś na to, że działania te mogły się nie powieść, że boskość (Elohim) nie jest pewnością. Słowami Caputo, mamy tu do czynienia z „pięknym ryzykiem tworzenia”. Drugi Bóg lub druga warstwa boskości z Księgi Rodzaju określana jest imieniem Jahwe (znowu, które nie jest imieniem, bo to jedynie określenie tego, który jest ${ }^{13}$ ). Jahwe ustala reguły funkcjonowania ludzi w raju, wyznacza w nim miejsce zakazane, pilnuje egzekwowania tego zakazu i w końcu ludzi z raju wypędza. To Bóg prawa, testowania ludzi pod kątem zgodności ich zachowań z narzuconą normą, kary za jej złamanie i wykluczenia. Te dwa wymiary boskości są przez Biestę odnoszone do ich inkarnacji w ciele wychowawcy (przypomnę, że to samo dotyczy polityków). Wracając do Rousseau, działania kształtujące ontologiczne warunki możliwości zaistnienia człowieka społecznego i ciała politycznego - niestwarzające niczego w sensie fizycznym, ale reorganizujące zastane środowiska - uprzedzają pojawienie się ludzi, którzy będą im poddawani. Są to działania na poziomie ontologicznym (tworzące warunki codziennego, „ontycznego” funkcjonowania ludzi) i są obarczone nieusuwalnym ryzykiem. Nie mamy pewności, jak dokładnie w tak wykreowanych warunkach zachowają się poszczególni - wolni przecież - ludzie. Ta animacyjna kreacja, a zatem sama konstruowalność doświadczanego przez nich świata, jest dla nich nierozpoznawalna aż do momentu wypracowania refleksyjnej samoświadomości, kiedy to pojawia się szansa retrospektywnego i analitycznego oglądu własnego doświadczenia. Z takim momentem mamy do czynienia u Emila (V księga), który na progu dorosłości, po powrocie z podróży mającej konfrontować jego wychowanie ze złożonością zewnętrznego świata, na pytanie nauczyciela o rezultaty podróży i o decyzje, jakie w jej efekcie podjął, odpowiada: postanowiłem zostać tym, czym mnie uczyniłeś. Emil jest teraz świadomy, że jego doświadczenia nie miały naturalnego charakteru, że były kontrolowane przez wychowawcę - ale skoro on sam został przez nie ukształ-

12 Tę trzecią opcję zawdzięczam uwadze Marii Mendel.

13 Por. w tym kontekście znakomity esej Ernesta Laclau o imionach Boga jako o nieuniknionej pustce znaczących odnoszących się do totalności, w tegoż The Rhetorical Foundations of Society. 
towany, pozostaje mu tylko je zaakceptować ${ }^{14}$. Bezpośrednio dostrzegalne działania wychowawcy i prawodawcy, rozgrywające się w sferze ontycznej, „w tym, co jest" i jest przedmiotem postrzegania poddawanych nim osób, mają charakter pozornie reaktywny. Wychowawca zdaje się jedynie odpowiadać na pytania Emila, ale to nie spontaniczność dziecka, tylko wcześniej stworzona przez samego wychowawcę scena jest realnym źródłem owych pytań. Razem z tymi dystrybucjami widzialności i niewidzialności figury wychowawcy i prawodawcy ulegają rozdwojeniu na boską, uprzedzającą kreację ontologicznych warunków, w których doświadczenie indywidualne i społeczne będzie przebiegać - oraz na wspierane ludzkim autorytetem i szacunkiem bezpośrednie normowanie i kierowanie przebiegiem tego doświadczenia.

Wrócę teraz do postawionego wcześniej pytania o znaczenie i skutki boskiej manipulacji boskimi istotami: ubóstwionymi przez naturę dziećmi i narodami przez ubóstwiających siebie nauczycieli i polityków. Jak sądzę, jest to kwestia nierozstrzygalna. Prawdopodobnie ten konflikt, ta kolizja leży u podstaw pedagogicznej winy wynikającej z poczucia najwyższej niestosowności bezpośredniej ingerencji w integralność dziecka, z lęku przed jej naruszeniem, przed ześlizgnięciem się na pozycję bezpośredniej dominacji. Jednocześnie - jako wychowawcy - musimy wychowywać, musimy podejmować interwencje i brać za nie odpowiedzialność. To zaś tylko wzmacnia dystynkcję widzialnego i niewidzialnego, rozdziela je do stopnia, w którym interwencja stanie się niewidzialna dla samego interweniującego i w którym sam podział na widzialne i niewidzialne staje się niewidzialny.

Najprościej można to zilustrować przez negację. Jak mogłaby wyglądać boska interwencja w boskość dziecka, gdyby nie owe zasłony i niemożności, możemy zilustrować obrazem Maxa Ernsta. Jego płótno Błogosławiona Dziewica karci Dzieciątko Jezus w obliczu trzech świadków: A.B., P.E., i Autora ${ }^{15}$, namalowane w 1926 roku w surrealistycznie „zgiętej” konwencji malarstwa renesansowego, typowego dla ikonografii kościołów katolickich, przedstawia Maryję zamaszyście tłukącą pośladki nagiego, leżącego na jej kolanach Jezuska. U jej stóp leży złota aureola, która najwyraźniej spadła dziecku z głowy. Obraz wywołał skandal i po interwencji katolickiego biskupa Kolonii został zdjęty z wystawy. Próba odpowiedzi na py-

${ }^{14}$ Jest to bardzo bliskie Heglowskiej figurze „gruntowania podstawy” z dialektyki tożsamości - fundamentem tożsamości Emila jest to, co retrospektywnie okazało się go ukształtować, na czym „wyrosło” to, czym się stał. Hegel ujmuje ten ruch tak oto: „Podstawa [der Grund, TS] jest jednością tożsamości i różnicy, prawdą tego, czym okazały się różnica i tożsamość - refleks yj ny m ki e rowaniem się ku sobie, które w tym samym stopniu jest refleksyjnym kierowaniem się ku temu, co in ne" (Hegel, 1990: 172; wyróżn. TS). Jak zauważa Slavoj Žižek, mamy tu do czynienia z wsteczna determinacją tożsamości. Takie jej pojmowanie jest bardzo istotne dla teorii Laclau. Por. Žižek, 1994.

15 Por. https://artblart.files.wordpress.com/2013/08/the-blessed-virgin-chastising-web.jpg 
tanie o przyczynę tego oburzenia jest istotna dla zrozumienia identyfikowanej tu gry deifikacji i profanacji. Najwyraźniej nie chodzi o sam fakt wymierzania kary cielesnej, bo taka forma pedagogicznej interwencji nie wydaje się sprzeczna z popularną wykładnią katolickiego wychowania i figura Maryi tłukącej Dzieciątko (oczywiście z miłością kierowaną troską o jego przyszłość) mogłaby znakomicie legitymizować katolicką pedagogikę rodziny. Tym, co wywołuje niepokój, zdaje się być niemożność połączenia - w akcie wychowawczej interwencji - dwóch figur boskości, dwóch figur pełni dobra i pełni władzy. Realizacja boskiego prawa do kontroli, wynikającego z autorytetu normatywnej figury Boga z rekonstrukcji Caputo, musi oznaczać profanację Jezusa. Zachowanie nietykalności Jezusa musi oznaczać bezsilność, ograniczenie sprawstwa i władztwa Maryi. Mówiąc krótko, wobec dziecka uznanego za bóstwo bezpośrednia interwencja okazuje się niemożliwa - zwłaszcza w przypadku wychowawcy również obdarzonego boskimi przymiotami miłości i autorytetu, dokładnie jak w uznanym za bluźnierczy obrazie Ernsta. Jakimś rozwiązaniem tego dylematu jest przyznanie naturalnej świętości wyłącznie dziecku nienarodzonemu, „poczętemu”, czystej potencjalności człowieka - przy zachowaniu autorytarnej formy wychowania (łącznie z prawem do bicia) dziecka już narodzonego. Przy bardziej konsekwentnym traktowaniu świętości życia dziecka narodzonego pozostają jedynie strategie wpływu niewidzialnego, wpływu prowadzącego do ujarzmienia woli dziecka realizowanego przez władzę nad „wszystkim, co je otacza”. W pajdocentrycznej pedagogice - podobnie jak nowoczesnym społeczeństwie nadzoru i dyscypliny - bezpośredniość wpływu musi ustąpić miejsca sztuce prowokacji, architektury, scenografii i rekwizytu. Sztuka ta musi także przeorganizować strukturę czasu.

\section{Konstrukcje temporalności}

Kategorie dotyczące czasu są niezwykle istotną osią pisarstwa pedagogicznego, które jest niemal nie do pomyślenia bez tego rodzaju wektorów: rozwój, opóźnienie, akceleracja, osiąganie celów, transmisja kulturowego dziedzictwa, przygotowanie do przyszłych ról społecznych czy uczenie się przez całe życie - wszystkie te pojęcia są zagnieżdżone w typowym dla nowoczesności czasie pojmowanym linearnie. Pedagogika najchętniej przy tym odwołuje się do przeszłości i do przyszłości, i - jak się zdaje - ciągle ma problem z teraźniejszością, z myśleniem o „tu i teraz" edukacji (por. Starego, 2016). Deficyt edukacyjnej teraźniejszości jest obecnie wyraźnie dostrzegany, podejmowane są krytyki tej temporalnej struktury oraz rozważania nad możliwością edukacji nieinstrumentalnej, „wolnej od 
przyszłości” - przynajmniej od przyszłości planowanej, z góry zakładanej jako cel kształcenia ${ }^{16}$. Jedną z najsilniejszych inspiracji takich poszukiwań jest filozofia Jacques'a Rancière'a, a szczególnie przedstawiona przez niego krytyka reform edukacyjnych inspirowanych teorią Pierre’a Bourdieu, zmierzających do eliminacji społecznych nierówności (Rancière, 1991). Jak zauważa Rancière, jeśli raz założymy w punkcie wyjścia nierówność, to działanie pedagogiczne kierowane intencją jej zniesienia będzie nieuchronnie tę nierówność powielać, przekształcając tylko jej postacie; wymarzona emancypacja nie zdarzy się nigdy. Jedynym sposobem przezwyciężenia tej pułapki jest radykalne założenie równości tu i teraz i działanie tak, jakby to założenie było prawdziwe (co Rancière nazywa weryfikacją). W odniesieniu do problematyki czasu mamy tu zatem do czynienia z przeniesieniem idei równości ze sfery celów (zawsze oddalonych i zawsze się oddalających) do sfery przedzałożeń, warunków pedagogicznego działania. Gert Biesta ${ }^{17}$ wprost zadaje w tym kontekście pytanie, czy czas da się „wyjąć" z repertuaru pojęć pedagogicznych i czy można myśleć o edukacji bez perspektywy przyszłości. Spora część badaczy reaguje na takie propozycje ze sceptycyzmem, twierdząc, że edukacja zawsze służyła i będzie służyć jakimś celom formułowanym poza nią samą. Dziś są to głównie cele związane z ekonomią (kształcenie dla rynku pracy czy dla innowacji gospodarczych) i ze sferą polityki (np. kształcenie dla demokracji, dla społeczeństwa wielokulturowego, itp.). Biesta odpowiada na takie krytyki przez rozróżnienie w pojęciu edukacji jego składowych instrumentalnych (jak socjalizacja i nabywanie kwalifikacji, zaznaczając, że nie są one swoiste dla edukacji - mogą przebiegać od niej niezależnie) oraz składowej upodmiotowienia (subjectification), która nie mieści się ani w logice instrumentalności (bo nie może być zaplanowana, „przydarza się" w efekcie skupionego na określonym przedmiocie nauczania), ani zarządzania czasem (Biesta, 2014). Krytycy kwestionują także odwoływanie się do Rancière’owskiego kontrfaktycznego założenia równości inteligencji („każdy może się nauczyć wszystkiego"). Czy można, pytają, opierać działania pedagogiczne na nieprawdziwych przesłankach? Pytanie to jest bardzo ważne dla zidentyfikowania istotnego wymiaru pedagogicznego dyskursu.

Trzeba zauważyć, że ani Rancière, ani przywoływany w jego książce XIX-wieczny wykładowca Joseph Jacotot, który takie podejście propagował, ani współcześni teoretycy poszukujący w tych ideach alternatywy dla dzisiejszego podporządkowania edukacji ekonomii i doraźnej polityce, nie są w perspektywie historycznej

${ }^{16}$ Por. na przykład Biesta, 2014; Biesta, Säfström, 2011; Masschelein, Simons, 2013; Bingham, Biesta, 2010, czy liczne artykuły T.E. Lewisa. W Polsce ten wątek był ostatnio podejmowany przez Karolinę Starego (Starego, 2016).

17 Por. na przykład Biesta, 2013. 
szczególnie wyjątkowi. Co więcej, warto się zastanowić, czy badana przez nich figura radykalnego założenia (u Rancière’a dotyczy ono równości), określana przez Charlesa Binghama (Bingham, 2010) mianem założeniowej tautologii (presumptive tautology) nie jest przypadkiem warunkiem jakkolwiek pomyślanej pedagogiki. Przypomnijmy: Johann Friedrich Herbart twierdził, że podstawowym pojęciem pedagogiki jest wychowalność (Bildsamkeit) człowieka. Inaczej mówiąc, podejmując działania pedagogiczne, musimy założyć, że człowieka da się wychować - i czynimy to wbrew ciągłym niepowodzeniom, wbrew tezom o naturalnej determinacji albo boskiej predestynacji ludzkiego życia: próbujemy ludzi kształcić i aby się takiego działania podjąć, musimy po prostu założyć, że człowiek nie jest w pełni zdeterminowany ani swoją naturą (w tym - co szczególnie ważne w kontekście historycznym - swoim „urodzeniem”), ani boskimi planami. U początków nowoczesnego projektu edukacji takie założenie musiało brzmieć skandalicznie: bycie „człowiekiem wychowanym” było prerogatywą elit i przyjmowanie takiego założenia w momencie konstruowania oświaty publicznej musiało brzmieć i niemądrze, i groźnie. Jeszcze wyraźniej widać to w przypadku Rousseau: jego teza o naturalnej dobroci człowieka także jest nieustannie kwestionowana przez doświadczenie. Jako sprzeczna z doktryną grzechu pierworodnego i rolą chrztu we wprowadzaniu człowieka na ścieżkę dobra była ona w czasach Rousseau skandaliczna także w sensie religijnym. Aby jednak podjąć próbę stworzenia dobrego społeczeństwa w sposób pozbawiony bezpośredniej przemocy wobec jednostek, trzeba było założyć, że jednostki mające takie społeczeństwo stworzyć są „dobre z natury”. Niemal dwieście lat później takie samo (i tak samo kontrfaktyczne) założenie przyjmował Carl Rogers. Pozwala to na rozwiązanie problemu zbudowania dobrego społeczeństwa przez ludzi wychowanych w złym i w dużej mierze wbrew społeczeństwu istniejącemu, łącznie z jego autorytetami i instytucjami. Wystarczy na jakiś czas odizolować młode pokolenia od wpływu złego świata, pozostawić je w środowisku zaprojektowanym w sposób oddający głos naturze (na wsi lub w demokratycznej szkole), aby doprowadzić do pojawienia się ludzi wolnych i silnych na tyle, by mogli się oni porozumieć w kwestii zawarcia społecznej umowy. Ten upór w zakładaniu naturalnego dobra i wychowalności jednostek miał swój kontekst polityczny. Czas Rousseau to czas rewolucji nadchodzącej, czas Herbarta to czas zgrozy po rewolucji zaszłej. Nie ma wątpliwości, że świat społeczny zmienić się musi. Wychowanie i publiczna edukacja rysują się w tym kontekście jako alternatywa dla masowego rozlewu krwi. Po prostu trzeba było założyć, że jest to możliwe.

Jak widzieliśmy u Rousseau, na poziomie konstrukcji teoretycznych tego rodzaju założeniowe tautologie przynoszą efekt w postaci zapętlających się struktur 
argumentacji. Taki charakter ma na przykład teza, że narody stają się sobą, gdy są formowane przez instytucje zorganizowane zgodnie $z$ ich naturą (RP). Tautologia założeniowa rodzi tautologie w sferze realizacyjnej. Próby poradzenia sobie z tautologiami w tych miejscach, które wymagają linearnego budowania racjonalnych, a zwłaszcza instrumentalnych argumentacji, uruchamiają z kolei szereg wspomnianych wcześniej retorycznych strategii konstruowania spójności, na przykład przez limitowanie widzialności projektowanych działań, w tym - przez lokowanie ich $w$ przeszłości samego doświadczenia edukacyjnego. Mamy tu do czynienia z bardzo specyficzną formą czasowości, jak przypuszczam - charakterystyczną właśnie dla teorii i strategii pedagogicznych (i z nich, jak się zdaje, przenoszoną do polityki), które chcą wstrzymywać się od bezpośredniej ingerencji w „naturalnie dobre" (a nawet święte i czcigodne) ciała podmiotów i suwerenów. Jak wspominałem we wstępnej części artykułu, nazwałem tę strategię temporalnym wykroczeniem. Przyjrzyjmy się następującemu cytatowi:

\footnotetext{
Pamiętaj, że zanim odważysz się przedsięwziąć formowanie człowieka, musisz przedtem sam stać się człowiekiem; musisz z samego siebie uczynić przykład, którym powinieneś być dla ucznia. Gdy dziecko nie ma jeszcze świadomości, mamy czas przygotować wszystkich, którzy się doń zbliżają, ażeby ukazywali jego oczom te tylko przedmioty, które są dla niego. Uczyń się godnym szacunku, zacznij od tego, żeby się dać lubić i żeby każdy starał się dogodzić ci. Nie będziesz rządził dzieckiem, jeżeli nie rządzisz wszystkim, co je otacza; a ta władza nie będzie nigdy dostateczna, jeżeli nie będzie oparta na poszanowaniu cnoty. (Rousseau, Em, par. 6.88)
}

Omawiane uprzednio strategie sakralizacji i profanacji są niewątpliwie $\mathrm{z}$ tą konstrukcją temporalności powiązane. Jej istotnym elementem jest omijanie teraźniejszości. Będziemy musieli zastanowić się nad tym, jaki retoryczny efekt takie ominięcie wywołuje i jak jest on związany z ontologiczną funkcją retoryki w publicznym dyskursie. Najpierw jednak chcę przedstawić jeszcze jeden wymiar pedagogicznej retoryki, jego opis zdaje się bowiem konieczny dla zrozumienia sensu tych gier w unikanie i zasłanianie teraźniejszości.

\section{Retoryka postulatu}

„Nauczyciel powinien...”, „szkoła powinna...” - teksty pedagogiczne nieustannie wykorzystują tego rodzaju zwroty. Powinnościowa, postulatywna retoryka zdaje się być jedną z najbardziej charakterystycznych cech dyskursu pedagogicznego. Co bardzo istotne, jest to retoryka w ścisłym sensie aksjologiczna. Chętnie przywoływana w tradycji pedagogicznej idealistyczna teoria wartości (np. Nicolai Hartmann, 
często cytowany w pracach Hessena ${ }^{18}$ ) ujmuje wartości jako nieistniejące, ale obowiązujące. Inaczej mówiąc, są one ideami określającymi pożądane, ale nieistniejące stany rzeczy, to, co „powinno” istnieć. Retoryka postulatywna przywołuje (a jak próbuję wykazywać, w zasadzie konstruuje) takie właśnie pojmowanie wartości - zakłada ona i praktykuje jako założeniową tautologię prymat tego, co być powinno, nad tym, co jest. Nasycenie dyskursu pedagogicznego tego rodzaju zwrotami jest wyrazem ukształtowania edukacji jako maszyny aksjologicznej transformującej jednostki i społeczeństwa w coś, czym aktualnie nie są. Takiej powinnościowej transformacji, jak widzimy u Rousseau, poddawana jest nawet natura (na przykład narodów). Oznacza to negowanie albo ignorowanie teraźniejszości, co może prowadzić do paradoksalnych skutków. Szczególnie interesujące jest użycie retoryki postulatu w sytuacji, gdy to, co postulowane, już istnieje. Czego doświadcza dziecko, które słyszy „powinieneś się postarać” w sytuacji, gdy właśnie się stara? „Dobrze by było, gdybyś czasem posprzątał”, gdy właśnie posprzątało? Tego rodzaju zwroty nie tylko odsyłają do tego, co być powinno, i nie tylko ignorują to, co jest: one unieważniają to, co jest. Staranie nie jest „staraniem”, porządek nie jest „porządkiem”: prawdziwy porządek i prawdziwe starania lokowane są gdzie indziej, w świecie, do którego nieustannie powinniśmy dążyć. Odwołując się do przykładu z manifestacji Jarosława Kaczyńskiego: prawdy nie ma, ona zawsze i tylko musi nadejść. Zwroty typu „prawda nadejdzie”, „jeszcze nie teraz, ale jesteśmy blisko” są chwytami retorycznymi wywołującymi efekt unieważniania prawdy, która jest. Powinność dążenia ku temu, czego nie ma, to aksjologiczna pompa wysysająca nas $\mathrm{z}$ aktualności; nihilistyczna w sensie Nietzscheańskim, nekrofilna maszyna odbierająca znaczenie życiu. Może ona mieć sens egzystencjalny tylko wtedy, gdy to życie jest nie do zniesienia i gdy jedynym jego sensem jest trwanie w nadziei, która się nigdy nie spełni - bo idealistycznie pojmowane wartości ze swej istoty nie mogą istnieć inaczej, jak w życiu przyszłym, w obowiązywaniu i w oczekiwaniu.

Odnosząc ten mechanizm do polityki teorii, możemy tu mówić o gestach unieważniania realności wychowania przez dyskurs aksjologicznie zorientowany na to, czego nie ma: na cele, na przyszłość, na oczekujący urzeczywistnienia potencjał. Retoryka postulatów dopisuje się w tym wymiarze do zidentyfikowanej wyżej retoryki czasu, do temporalnych wykroczeń lokujących działanie pedagogiczne w przeszłości po to, by kontrolować przyszłość - co jest manipulacją pozwalającą na ograniczenie bądź wręcz wyłączenie (jak u Rousseau) teraźniejszości z bezpośrednich form pedagogicznego nadzoru, a zatem na uczynienie pracy pedagogicznej niewidzialną dla wychowywanych podmiotów.

18 Por. na przykład Hessen, 1997. 
Przywoływane wcześniej poszukiwania „tego, co edukacyjne w edukacji” (Biesta, Bingham, Lewis, Masschelein, Säfström...) muszą w tym kontekście dystansować się wobec tego, co stało się znakiem wyróżniającym pedagogiki - jej orientacji aksjologicznej na to, czego jeszcze nie ma. Wspomniani autorzy dopowiadają za Rancièrem: i nigdy - w takiej teoretyczno-praktycznej konfiguracji, jaką sobie wypracowaliśmy - nie nadejdzie.

\section{Powrót niewidzialnego i pytanie o ideologię}

Retoryczna konstrukcja dystynkcji między widzialnym i niewidzialnym, analizowana przeze mnie w treści poszczególnych elementów teorii, powtarza się zatem w samej konstrukcji podstaw teorii pedagogicznej. Patrząc na to genealogicznie, w zasadzie powinniśmy odwrócić tę zależność: to sam zamiar teoretyzowania edukacji jako działania zorientowanego na przyszłość, osadzający ją w grze istnienia i nieistnienia, bytu i wartości, uruchamia dziesiątki strategii i setki wewnętrznych taktyk widzialności i niewidzialności, różnicujących się w zależności od cech poszczególnych przypadków uniwersalnego, typowego dla nowoczesności napięcia między ideałami wolności indywidualnej i ideami racjonalnego społecznego porządku.

Takie strategie mają znaczenie nie tylko dla samej teorii, nie tylko w kontekście jej spójności bądź niespójności. Co więcej, nie tylko dla osób będących bezpośrednimi odbiorcami ich przekazu - jak nauczyciele akademiccy i kształceni przez nich nauczyciele szkół publicznych. Teorie są częścią kultury, wiążą się z innymi tekstami kultury, i co szczególnie ważne, są częścią kultury „zaktualizowanej”, uświadamianej: tej jej warstwy, którą określamy mianem dyskursu publicznego. W tym dyskursywnym wymiarze wiążą się one z praktykami nazywania i nienazywania określonych zjawisk, z pragmatyką językową, z określonymi politykami społecznymi; powołują do życia pewne byty, gdy innych nie powołują, wiążą je w określone kompleksy, które określają prawdopodobne i nieprawdopodobne interpretacje, światy możliwe i niemożliwe. Odwołując się do terminologii J. Rancière’a, teorie społeczne lokują się wśród praktyk dzielenia postrzegalnego i w tym sensie są elementem polityki rozumianej jako konstruowanie ludzkich wspólnot.

Jak w takim kontekście można rozumieć polityczną rolę konstruowanej w językach teoretycznych niewidzialności? Inaczej: jak można określić udział teorii pedagogicznych - jako elementów dyskursu publicznego - w konstruowaniu wspólnot politycznych? Interesują mnie tu kwestie związane z samą logiczną i retoryczną strukturą teorii, a nie $\mathrm{z}$ ich aplikacjami, implementacjami w oświatowych 
politykach itp. - te sprawy są bowiem dość jasne. Chodzi mi zatem o politykę teorii pedagogicznych rozumianą w kontekście specyficznych dla nich strategii dzielenia postrzegalnego, tworzenia reguł publicznej widzialności i niewidzialności określonych społecznych praktyk i obiektów. Muszę to ująć bardzo skrótowo, wspomnę zatem jedynie, że udaje się zidentyfikować takie strategie nie tylko w tekstach Rousseau. Są one - z oczywistymi modyfikacjami - replikowane i rozwijane także u J.F. Herbarta, w polskiej pedagogice socjalistycznej czy w pedagogicznych ujęciach koncepcji uczenia się całożyciowego i społeczeństwa wiedzy ${ }^{19}$. I prawdopodobnie w wielu innych teoretycznych propozycjach. Skupię się teraz wyłącznie na niewidzialności możliwej do zidentyfikowania w relacji teorii do ich społecznych i politycznych kontekstów - głównie przez pryzmat opisanej wyżej retoryki postulatywnej. Oto zatem kilka skrótowych prezentacji problemu.

J.F. Herbart postuluje zanurzenie dziecka w ,jakby płynnym środowisku”, które w niemal niezauważalny dla niego sposób wspiera lub delikatnie utrudnia niektóre jego zachowania. Taki opis jest metaforycznym wyjaśnieniem sposobu działania dyscypliny. W odróżnieniu od rządu nad dziećmi (bezpośredniej ingerencji dorosłych w zachowanie dziecka) dyscyplina obejmuje nie tylko zachowania fizyczne i ich skutki, ale także niewypowiedziane intencje. Ta instancja - niewidzialna dla dziecka - powstaje w efekcie interioryzacji bezpośredniego nadzoru. Opis Herbarta jest uderzająco podobny do rekonstrukcji nowoczesnej władzy dyscyplinarnej w pracach Michela Foucaulta. Jeśli Foucault trafnie opisuje proces powstawania społeczeństwa dyscyplinarnego (a raczej nie ma co do tego wątpliwości), to w czasie, gdy Herbart pisał swoją Pedagogikę ogólna... (pierwsze wydanie w roku 1806), społeczeństwo takie niewątpliwie już istniało. Otoczenie Herbarta było przesycone praktykami dyscyplinarnej kontroli. Herbart tego rodzaju praktyk jednak nie opisuje - zgodnie z logiką teorii projektującej rzeczywistości pożądane są one postulowane tak, jakby nie istniały. Rodzi to pytanie o to, jaką rolę w przestrzeni nasyconej takimi praktykami może odgrywać teoria ignorująca ich istnienie i instruująca, jak je powoływać do życia. Dodam, że metaforyczny opis dyscypliny w Pedagogice ogólnej... nie jest jedynie językowym ozdobnikiem na ogół precyzyjnego i dość „suchego" tekstu; metafora płynnego środowiska zdaje się być jedynym dostępnym środkiem opisu tej instancji, bowiem jej postulowana niewidzialność usuwa ją, w sensie metodologicznym, poza zakres obiektów dających się badać w sposób naukowy, u Herbarta wyznaczany standardami nauk przyrodniczych. To znaczące dla teorii Herbarta pojęcie nie ma zatem jasnej definicji.

19 Te cztery (łącznie z Rousseau) artykulacje dyskursu pedagogicznego analizuję w książce On the Politics of Educational Theory... 
Polska pedagogika społeczeństwa wychowującego, rozwijana głównie w latach siedemdziesiątych XX wieku, projektuje systemowe modele sieci instytucji wychowawczych ze wszystkich stron otaczających uczące się podmioty. Koncepcje te zakładają systematyczne, koordynowane przez szkoły oddziaływania mające przełamać kryzys wywołany młodzieżowymi rewoltami końca lat sześćdziesiątych. Modele te powstały w czasie, gdy stopień kontroli państwa nad procesami socjalizacji i wychowania, a także stopień koordynacji tych oddziaływań między poszczególnymi instytucjami, był bezprecedensowy - szkoły, osiedla mieszkaniowe, organizacje młodzieżowe i stowarzyszenia, kluby sportowe, fabryki, gospodarstwa rolne, wojsko - nie jestem w stanie opisać całego tego konglomeratu - brały udział w zmasowanej „walce o przyszłość kraju” koordynowanej przez specjalistów (pedagogów zatrudnianych nie tylko w szkołach, ale też w spółdzielniach mieszkaniowych, fabrykach, klubach młodzieżowych, jednostkach wojskowych itp.), prowadzonej „na froncie” wychowania młodzieży. Co szczególnie interesujące, postulaty budowy skoordynowanego systemu wychowania posługiwały się pojęciem społeczeństwa wychowującego, które zostało zapożyczone z socjologii Floriana Znanieckiego. W latach dwudziestych Znaniecki traktował to pojęcie jako kategorię opisową: w jego rozumieniu społeczeństwa sq społeczeństwami wychowującymi. W latach siedemdziesiątych, gdy funkcje wychowawcze społeczeństwa polskiego zostały rozbudowane do niewyobrażalnych dziś rozmiarów i poddane niemal totalnej instytucjonalnej kontroli, opisowa kategoria społeczeństwa wychowującego wysublimowała się do rangi ideału, do oczekiwanego (zatem nieistniejącego w pełni, wymagającego pracy, walki i zbiorowej koncentracji) modelu społeczeństwa "prawdziwie" wychowującego, prawdziwie socjalistycznego.

Raport UNESCO, napisany pod kierunkiem Jacques’a Delorsa (Delors, 1998), będący wyrazistym znakiem rozpoczynającej się inwazji uczenia się, osadza tę kategorię w dyskursie humanistycznych wartości i przypisuje uczeniu się rolę czynnika przezwyciężającego chyba wszystkie aporie i konflikty nowoczesnego świata. Dzięki uczeniu się ma nastąpić pojednanie jednostki i społeczeństwa, przeszłości z przyszłością, globalności i lokalności, partykularyzmu i uniwersalizmu etc. - już sama lista tych opozycji zapewnia nas, że uczenie się jest tutaj ulokowane na pozycji hegemonicznego, pustego znaczącego. Jednocześnie Delors posługuje się metaforą, która jednoznacznie wpisuje ten koncept w dyskurs ekonomiczny: uczenie się jest skarbem zapewniającym bogactwo porównywalne z tym, jakie dawniej zapewniała własność ziemi i ciężka praca. Inaczej mówiąc, wartość skarbu w dosłownym, ekonomicznym sensie, metaforycznie ugruntowana we wszechogarniającej, panhumanistycznej wartości zniesienia wszelkich barier i niemożności, zostaje zainwestowana w edukację, która w ten sposób staje się moralnie uzasadnionym 
kapitałem. Skoro zaś jest kapitałem, to musi - wbrew idealistycznej retoryce zniesienia wszelkich sprzeczności - zakładać wykluczenia, tworzenie obszarów niewiedzy i ugruntowanej ignorancji. Kapitałem nie może być nic, co jest powszechnie dostępne - przypominałoby to logikę bohaterów Autostopem przez galaktykę Adamsa, którzy po kolonizacji pewnej planety wybrali liście jako obowiązujący środek płatniczy. Transformacja kapitału w wiedzę i uczenie się podąża dokładnie takim samym tropem wywłaszczeń i tworzenia klasy wykluczonych z własności robotników, jak ta, którą w czasach eksplozji przemysłu opisywał Marks. Mamy już mnóstwo publikacji dokumentujących aktywne polityki zarządzania ignorancją w gospodarce opartej na wiedzy ${ }^{20}$.

Co łączy te przypadki dyskursu pedagogicznego? Wszystkie zostały tu opisane pod kątem retoryki postulatywnej (dyscyplina, społeczeństwo wychowujące i uczenie się są tym, co powinniśmy osiągnąć). Konsekwencje są tutaj podobne do tych, które opisywałem poprzednio. Postulowanie czegoś operuje podwójnym gestem: z jednej strony zasłania to, co jest już rozpowszechnione (dyscyplinarną kontrolę społeczeństw, rozbudowaną do granic możliwości instytucjonalną kontrolę państwa nad procesami socjalizacji, dokonujące się przedefiniowywanie edukacji jako ekonomicznie, rynkowo rozumianego uczenia się). Z drugiej - czyni $\mathrm{z}$ tego, co postulowane, wartość, co z kolei utrudnia dostrzeganie negatywnych skutków w taki sposób sublimowanych praktyk (np. systematycznego wykluczenia dużych grup społecznych z dostępu do znaczącej wiedzy w procesie jej kapitalizacji). Różnica jest taka, że tym razem mówimy nie o wewnętrznej retoryce języka teoretycznego pedagogiki, podporządkowanej celom budowania i podtrzymywania spójności argumentacji tam, gdzie w sposób logiczny zbudować się jej nie da, a o zewnętrznej, ontologicznej retoryce dyskursu publicznego. Mówimy zatem o polityce teorii sensu stricto, o pracy teorii w obszarze konstruowania hegemonii, tworzenia i podtrzymywania określonych społecznych porząaków, a także o ochronie wynikających z tych porządków nierówności i przywilejów.

Czy można zatem powiedzieć, że pedagogika stanowi fałszywą świadomość społeczeństw nowoczesnych, że jest po marksowsku rozumianą ideologią?

Przedstawione tu przypadki zdają się taka tezę potwierdzać. Zilustruję to, wracając do przykładu teorii Herbarta i jej milczenia na temat zidentyfikowanej przez Foucaulta władzy dyscyplinarnej. Aby to ująć dokładniej, musimy dokonać rozróżnienia między pedagogizmem a pedagogiką. Tym pierwszym terminem określiłem kiedyś nasycenie relacji społecznymi praktykami o edukacyjnym charakterze, przede wszystkim właśnie praktykami dyscyplinarnymi niezbędnymi w procesie

20 Por. na przykład Jessop, 2007; Roberts, Armitage, 2008; Proctor, Schiebinger, 2008. 
kreowania, motywowania i wspierania podmiotowej autonomii jednostek - autonomii rozumianej jako panowanie nad sobą, które, jak wiemy od Kanta, Foucaulta, Piageta czy Hessena, jest efektem uwewnętrznienia panowania zewnętrznego (Szkudlarek, 1995). Do rozpowszechnienia tego rodzaju praktyk zarządzania sobą niezwykle silnie przyczynił się przełom kulturowy związany z reformacją chrześcijaństwa. Tworzenie systemu edukacji powszechnej miało miejsce na jego tle i w jego logice. Pedagogika - jako dyscyplina akademicka, a zatem jako logicznie i retorycznie specyficzny język - pojawia się natomiast po tym religijnym i kulturowym przełomie, wraz z instytucjonalizacją wyabstrahowanych z kontekstów religijnych, rzemieślniczych, penitencjarnych, militarnych, rodzinnych etc. technik dyscyplinowania rozumianych jako techniki władztwa nad sobą, konstruowania „ja” jako podmiotu racjonalnego i autonomicznego. Pedagogika byłaby zatem kulturową świadomością logiki owych praktyk, umożliwiającą gromadzenie, klasyfikowanie, produkowanie, systematyzowanie i dystrybucję wiedzy opisowej i technicznej dotyczącej nowoczesnego formowania podmiotu. Wiedza ta stawia jednak podmiot nie tyle w pozycji faktu społecznego życia, bytu wygenerowanego na drodze rozpleniających się praktyk dyscyplinarnych, ile w pozycji wartości. Pedagogika operująca kategorią podmiotu jako wartością postuluje zatem dyscyplinowanie jednostek na drodze do ich autonomii i jednocześnie - jak widzimy to nieustannie $\mathrm{w}$ teoretycznych debatach $\mathrm{w}$ ramach tej dyscypliny wiedzy ${ }^{21}$ - nieustannie wpada w zdumienie nad sprzecznościq świadomego organizowania i praktykowania dyscypliny z jednej, i traktowania podmiotu jako wartości naczelnej z drugiej strony. Jak próbowałem to wykazać, ta „niedogodność” tkwi u źródeł dyskursu pedagogicznego i zdaje się mieć charakter dla niego konstytutywny, jest prawdopodobnie nieusuwalna. To zdumienie, a często wręcz sprzeciw, zdaje się w tym kontekście pozwalać na stanowcze wyparcie i retoryczne zasłonięcie genetycznego związku autonomii podmiotu $\mathrm{z}$ heteronomią nadzoru. Pedagogika - szczególnie w humanistycznej i emancypacyjnej postaci - zdaje się mozolnie utrudniać rozumienie podstawowej logiki władzy w społeczeństwach nowoczesnych, stając się w ten sposób istotnym, a może wręcz niezbędnym czynnikiem umożliwiającym płynne realizowanie logiki tej władzy. W tym wymiarze pedagogika jest rzeczywiście ideologią.

Rzecz nie jest jednak (na szczęście) tak jednoznaczna, i to co najmniej z dwóch powodów. Po pierwsze, władza nowoczesna nie jest sprawowana „z góry na dół”, nie jest tradycyjnie pojmowaną przemocą - wspieranie jej logiki, dające się za-

${ }^{21}$ Pojawianie się pojęcia dyscypliny zarówno w odniesieniu do formowania podmiotu, jak i do organizowania wiedzy nie jest zbieżnością przypadkową. Por. rozdział na temat teorii Herbarta w The Politics of Educational Theory... 
kwalifikować jako ideologia w marksowskim sensie, nie jest zatem tożsame z zaprzepaszczaniem idei emancypacji. Inaczej mówiąc, w świetle teorii hegemonii (Gramsci, Laclau, Mouffe) wyjściowa dla pedagogiki i wciąż dotkliwie odczuwana sprzeczność między wolnością podmiotu i konstruowaniem społeczeństwa okazuje się względna; obie te wartości sytuują się wobec siebie jako w pewnym wymiarze antagonistyczne i jako ze sobą współdziałające. To dlatego źródłowy dla tej kwestii język Rousseau jest tak silnie nasycony paradoksami i tak często odwołuje się do narzędzi retorycznych. Po drugie, trzeba wziąć pod uwagę rolę pustych znaczących (a z nimi negatywności jako locusu etyki) w tworzeniu społecznych totalności. Ta kwestia, wraz z dyskusją o roli pedagogiki i praktyki edukacyjnej w tworzeniu pustych znaczących, znalazła się poza zakresem przedstawionych tu analiz. Szersze wyjaśnienia na ten temat znajdują się w innych moich publikacjach. W największym skrócie można to ująć tak, że dyskurs pedagogiczny zarówno w jego warstwie teoretycznej, jak i w codziennych praktykach komunikacyjnych w klasach szkolnych - jest nadmiarowy w stosunku do zarysowanych tu funkcji ideologicznych. Edukację można tu traktować jako „fabrykę pustych znaczących", co silnie wiąże się z jej aksjologicznym wymiarem. Przypomnę, że wartości charakteryzują się specyficzną, powinnościową (więc w dosłownym sensie nierealną) formą istnienia. Orientacja edukacji na wartości oznacza między innymi to, że i w praktyce, i w teorii musimy podejmować próby ich definiowania, a te nieuchronnie prowadzą do niekończącej się multiplikacji ich znaczeń. Ani w debatach teoretycznych, ani w praktyce szkolnej żadna z kategorii w rodzaju podmiotu, społeczeństwa, emancypacji, wychowania czy wartości, a także przyjaźni, patriotyzmu, mądrości, czy miłości nie uzyska jednoznacznej definicji podobno istotnej ich roli w wypełnianiu przyszłościowej „misji” edukacji. Namiętne debaty na „humanistycznie produktywne” tematy (Czym jest dziś patriotyzm? Czy szczęście jednostki jest ważniejsze od obowiązku wobec innych?) kończą się zwykle nauczycielskimi ocenami w rodzaju „masz rację”, „i ty też masz rację”, „to wszystko prawda, ale tu chodzi jeszcze o coś więcej”. Właśnie to niedefiniowalne „coś więcej”, semantyczna pustka tego, o co chodzi najbardziej, jest warunkiem hegemonicznej roli pustych znaczących, które - po to, aby integrować to, co jest wzajemnie sprzeczne (jak żądania wcześniejszych i jednocześnie wyższych emerytur), albo to, co po prostu żądnego związku ze sobą nie ma (jak aktywna polityka historyczna i niekotrolowane wycinanie drzew ${ }^{22}$ ) - nie mogq w żadnym wypadku uzyskać precyzyjnego znaczenia. Ten aspekt produkowania pustych znaczących możemy uznać za współdziałający w konstruowaniu hegemonii, wpisujący się

22 Te przykłady pochodzą z aktualnego dyskursu publicznego w Polsce. 
$\mathrm{w}$ omawiany poprzednio ideologiczny wymiar pedagogiki. Ale ta sama semantyczna pustka jest miejscem, w którym pojawia się etyczność: negatywnością, która jest wiecznie pustym miejscem na nieosiągalną pełnię, która pozwala na krytyczny dystans do wszelkiej zaktualizowanej hegemonii („To przecież nie to! To nie o to chodziło!"). Sądzę, że intensywność, z jaką w procesie edukacji produkujemy niedefiniowalność wartości - zarówno przez spory i polemiki teoretyczne, jak i przez typową i dla naukowych konferencji, i dla lekcji humanistyki gadaninę, niekończące się głoszenie referatów i pisanie „wypracowań” o wartościach, bohaterstwie, dialogu, miłości, o poświęcających się matkach i przedsiębiorczych ojcach, przez wieczne mnożenie milionów przykładów z empirycznych badań, życiowej praktyki i z literackich fikcji, które w żaden sposób nie dają się logicznie uspójnić pod jedną etykietą - jest niezwykle istotna w sensie politycznym, rozumianym znacznie szerzej niż w przypadku ideologicznej pracy dyskursu zasłaniającego strukturę hegemonii. W tym samym momencie, obok praktyk zasłaniania tego, co jest, utrudniania rozumienia procesów społecznych, i legitymizowania aktualnych hegemonii, edukacja tworzy bowiem rezerwuary "chwilowo zbędnych” znaczeń niepełnych, niedookreślonych, semantycznie opróżnianych z jednoznaczności; znaczeń jeszcze niezużytych w pracy ideologii, jeszcze pociągających obietnicami pełni, jeszcze czekających na swój czas, gdy to, co ważne obecnie, znudzi się i zużyje; znaczeń zapowiadających przyszłe tożsamości i przyszłe walki o hegemonię. Nawiązując do klasycznej dystynkcji Karla Mannheima (Mannheim, 2008), można powiedzieć że dyskurs pedagogiczny jednocześnie i mozolnie wytwarza retoryczne zasoby dla legitymizujących to co jest ideologii - i dla kwestionujących status quo utopii. Jeśli zatem pracuje dla przyszłości, to naprawdę - i chyba na szczęście - nie wiadomo dla jakiej.

\section{Literatura}

Agamben G. (2007). Profanations. New York.

Baczko B. (1964). Rousseau: Samotność i wspólnota. Warszawa.

Baker B. (2010). In Perpetual Motion. Theories of Power, Educational History, and the Child. New

York, Washington D.C., Bern, Franfurt am Mein, Berlin, Brussels, Vienna, Oxford.

Biesta G. (2013). Time out: can education do and be done without time? [W:] T. Szkudlarek (red.).

Education and the Political. New Theoretical Articulations. Rotterdam, Boston, Taipei.

Biesta G. (2014). The Beautiful Risk of Education. New York.

Biesta G., Säfström C.A. (2011). A Manifesto for education. „Policy Futures in Education” 9(5).

Bingham Ch. (2010). Under the name of method: On Jacques Rancière's presumptive tautology. [W:]

C. Ruitenberg (red.). What do Philosophers of Education do (And how they do it)?. Hoboken. 
Bingham Ch., Biesta G. (2010). Jacques Rancière: Education Truth, Emancipation. New York.

Carusi F.A. (2011). The Persistence of Policy: A Tropological Analysis Of Contemporary Education Policy Discourse in the United States. „Scholar Works”. https://scholarworks.gsu.edu/eps_diss/82/, dostęp: 29.11.2015.

Carusi F.A. (2017). Why Bother Teaching? Despairing the Ethical Through Teaching that Does Not Follow, „Studies in Philosophy and Education”. doi:10.1007/s11217-017-9569-0.

Delors J.,(red.). (1998). Edukacja - jest w niej ukryty skarb. Warszawa.

Hegel G.W.F. (1990). Encyklopedia nauk filozoficznych. Warszawa.

Hessen S. (1997). O sprzecznościach i jedności wychowania. Warszawa.

Inston K. (2010). Rousseau and Radical Democracy. London and New York.

Jessop B. (2007). Knowledge as a fictitious commodity: Insights and limits of a Polanyian analysis.

[W:] A. Buiğra, K. Ağartan (eds.) Reading Karl Polanyi for the 21st Century: Market Economy as a Political Project. Basingstoke.

Laclau E. (2009). Rozum populistyczny. Przekład zespołowy pod kier. T. Szkudlarka. Wrocław.

Laclau E. (2014). The Rhetorical Foundations of Society. London.

Mannheim K. (2008). Ideologia i utopia. Przeł. J. Miziński. Warszawa.

Masschelein J., Simons M. (2013). In Defence of the School: A Public Issue. Leuven.

Osterwalder F. (2012). The Modern Religious Language of Education: Rousseau's Emile. „Studies in Philosophy and Education" 31.

Proctor R.N., Schiebinger L. (red). (2008). Agnotology: The Making and Unmaking of Ignorance. Stanford.

Rancière J. (1991). The Ignorant Schoolmaster. Five Lessons in Intellectual Emancipation. Stanford.

Roberts J., Armitage J. (2008). The Ignorance Economy, „Prometheus” 26, 4.

Rousseau J.-J., (1762), Émile ou de l'éducation: livres I, II et III. http://classiques.uqac.ca/classiques/ Rousseau_jj/emile/emile_de_education_1_3.pdf.

Rousseau J.-J. (1966). Uwagi o rządzie polskim. [W:] Umowa społeczna oraz Uwagi o rzadzie polskim. Przedmowa do „Narcyza”. List o widowiskach. List o opatrzności. Listy moralne. List do arcybiskupa de Beaumont. Listy do Malesherbesa. Przekład B. Baczko, W. Bieńkowska, M. Pawłowska, A. Peretiatkowicz, J. Rogodziński, M. Staszewski, B. Strumiński. Warszawa.

Rousseau J.-J. (2007). Umowa społeczna. Przekład A. Peretiatkowicz. Kęty.

Rousseau J.-J., Emil, czyli o wychowaniu. Polska Biblioteka Internetowa (epub), b.r.w.

Scott J. (1994) Politics as the imitation of the divine in Rousseau's Social Contract. "Polity" XXVI, pp. 473-501.

Starego K. (2016). Odmowa teraźniejszości, czyli o odobywatelnianiu dzieci i udziecinnianiu obywateli. „Teraźniejszość - Człowiek - Edukacja” 19, 3(75).

Szkudlarek T. (1995). Pedagogizm i pedagogika. [W:] J. Hejnicka-Brzezwińska (red.), Racjonalność pedagogiki. Bydgoszcz.

Szkudlarek T. (2005). On nations and children: Rousseau, Poland, and European Identity. „Studies in Philosophy and Education", 24. pp. 19-38.

Szkudlarek T. (2007). Empty signifiers, politics and education. „Studies in Philosophy and Education” $26(3)$.

Szkudlarek T. (2011). Semiotics of identity. education and politics. „Studies in Philosophy and Education" 30 (2).

Szkudlarek T. (2013). Identity and normativity: politics and education. [W:] T. Szkudlarek (red.). Education and the Political. New Theoretical Articulations. Rotterdam, Boston \& Taipei. 
Szkudlarek T. (2016). Retoryka tożsamości. [W:] Przesilenie. Nowa kultura polityczna pod red. J. Kołtana. Gdańsk.

Szkudlarek T. (2017). On The Politics of Educational Theory. Rhetoric, theoretical ambiguity, and the construction of society. London and New York.

Tröhler D. (2014). Between universally claimed theory and a common understanding: Theoretical knowledge in education. [W:] G. Biesta, G. Allen, R. Edwards (eds.). Making a Difference in Theory. The Theory Question in Education and the Education Question in Theory. London and New York.

Žižek S. (1994). Identity and its vicissitudes: Hegel's ,Logic of Essence' as theory of ideology. [W:] E. Laclau (ed.). The Making of Political Identities. London. 